\title{
PENGARUH FRAKSI VOLUME SERAT TERHADAP SIFAT MEKANIK KOMPOSIT SERAT TEBU/POLIESTER
}

\author{
Siska Titik Dwiyati, MT \\ Jurusan Teknik Mesin, Fakultas Teknik, Universitas Negeri Jakarta \\ e-mail : siska.td@gmail.com
}

\begin{abstract}
ABSTRAK
Pada penelitian ini dilakukan studi penggunaan limbah serat tebu sebagai penguat pada komposit polimer dengan matrik poliester. Tujuan dari penelitian ini adalah untuk mengetahui nilai kekuatan tarik, kekakuan dan ketangguhan komposit serat tebu/poliester serta melihat pengaruh fraksi volume serat terhadap sifat mekanik. Pada penelitian ini fraksi volume serat divariasikan yaitu $5 \%, 15 \%, 25 \%$ dan 35\%. Pengujian mekanik dilakukan dengan mesin uji tarik dan menggunakan standar uji ASTM D 638. Hasil pengujian tarik menunjukkan bahwa untuk fraksi volume 5\% memiliki kekuatan tarik 14,4 MPa, fraksi volume 15\% memiliki kekuatan tarik 17,6 MPa, fraksi volume 25\% memiliki kekuatan tarik 20,5 MPa, dan fraksi volume 35\% memiliki kekuatan tarik $23 \mathrm{MPa}$. Adapun nilai kekakuan untuk komposit dengan fraksi volume serat 5\%, 15\%, 25\%, 35\% masing-masing sebesar $652 \mathrm{MPa}, 786 \mathrm{MPa}, 827 \mathrm{MPa}, 885 \mathrm{MPa}$. Nilai ketangguhan sebesar 31,8 Joule, 39,4 Joule, 50,8 Joule,59,8Joule.
\end{abstract}

Kata kunci: Fraksi volume, serat tebu, poliester

\section{PENDAHULUAN}

Penggunaan material komposit dalam bidang rekayasa semakin berkembang. Hal ini disebabkan sifat-sifat komposit yang unggul dibandingkan dengan bahan konvensional lainnya yaitu; ringan, memiliki sifat mekanik yang baik, tahan lama, tahan korosi, mudah difabrikasi dan biaya produksi yang relatif murah.

Seiring dengan pesatnya perkembangan teknologi plastik sejak tahun 1990-an, teknologi komposit bermatrik polimer juga ikut mengalami perkembangan dengan pertumbuhan mencapai sekitar $3,8 \%$ pertahun. Bahkan pada dasawarsa terakhir, kecenderungan perkembangan material komposit bergeser kepada penggunaan kembali serat alam sebagai pengganti serat sintetik. Hal ini didukung oleh beberapa keunggulan yang dimiliki oleh serat alam yaitu bersifat elastis, kuat, massa jenisnya rendah, terbaharukan, proses produksi memerlukan energi yang rendah dan ramah lingkungan, serta mempunyai sifat sebagai isolator panas dan akustik yang baik.

Penggunaan kembali serat alam, juga dipicu oleh adanya regulasi tentang persyaratan habis pakai produk komponen otomotif bagi negaranegara Uni Eropa dan sebagian Asia. Sejak tahun 2006,

negara-negara Uni Eropa telah mendaur ulang $80 \%$ komponen otomotif, dan akan meningkat menjadi $85 \%$ pada tahun 2015 . Di Asia khususnya Jepang, sekitar $88 \%$ komponen otomotif telah di daur ulang pada tahun 2005 dan akan meningkat pada tahun 2015 menjadi 95\%.

Meskipun demikian sampai saat ini komposit serat alam belum banyak diproduksi di Indonesia. Padahal Indonesia memiliki prospek yang sangat baik karena mayoritas tanaman penghasil serat alam dapat dibudidayakan di Indonesia misalnya serat kenaf, tebu, rami, rosella dan nanas-nanasan. Jika tanaman ini dikembangkan, tentunya hal tersebut akan mampu meningkatkan pemberdayaan sumber daya alam lokal yang dapat diperbaharui.

Tanaman tebu merupakan tanaman penghasil serat. Serat tebu merupakan limbah yang dihasilkan pada pengolahan batang tebu menjadi gula. Pada penelitian ini akan dilakukan pembuatan komposit serat tebu-poliester dengan variasi fraksi volume serat $5 \%, 15 \%, 25 \%$ dan $35 \%$. Terhadap komposit tersebut, kemudian dilakukan pengujian sifat mekanik untuk mellihat pengaruh fraksi volume serat tebu tersebut terhadap sifat mekanik komposit.

\subsection{Komposit Matrik Polimer}

Serat pada komposit berfungsi sebagai penguat. Secara alami serat yang panjang mempunyai kekuatan yang lebih tinggi dibanding serat pendek. Serat panjang mempunyai struktur yang lebih sempurna karena struktur kristalnya tersusun sepanjang sumbu serat dan cacat internal pada serat lebih sedikit dari pada serat pendek. 
Bahan pangikat atau penyatu serat dalam material komposit disebut matriks. Matriks berfungsi sebagai penyelubung serat dari kerusakan antar serat berupa abrasi, pelindung terhadap lingkungan (serangan zat kimia, kelembaban), pendukung dan menginfiltrasi serat, transfer beban antar serat, dan perekat serta tetap stabil secara fisika dan kimia setelah proses manufaktur. Matriks dapat berbentuk polimer, logam, karbon, maupun keramik. Komposit berbasis polimer dibagi menjadi dua sesuai dengan jenis polimer yang digunakan, yaitu termoplastik (dapat didaur ulang) misalnya produk dash board mobil,bemper mobil, casing komputer, casing HP dan termoset (tidak dapat didaur ulang) misalnya kanvas rem, seal hidrolik, skin plate [1].

Gabungan matriks dan serat dapat menghasilkan komposit yang mempunyai kekuatan dan kekakuan spesifik yang lebih tinggi dari bahan logam, keramik dan polimer. Hal ini disebabkan komposit mempunyai densitas jauh lebih rendah dibanding dengan bahan konvensional. Selain itu produk komposit yang dihasilkan akan mempunyai derajat pengerutan yang lebih rendah dibandingkan dengan logam. Pengurangan berat yang disebabkan penggunaan komposit sangat penting dalam industri otomotif dan penerbangan, karena cukup signifikan dalam menghemat bahan bakar.

Pada industri penerbangan kecendrungan untuk menggantikan komponen logam dengan komposit juga disebabkan oleh ketahanan fatik yang baik, terutama pada komposit yang menggunakan serat karbon.

Keunggulan komposit yang lainnya adalah ketahanannya terhadap korosi. Sifat ini dapat mengatasi kelemahan logam yang mudah mengalami korosi, sehingga biaya pembuatan dan perawatan produk menjadi tinggi. Komposit juga dapat menghasilkan produk yang merupakan gabungan sifat-sifat menarik yang dihasilkan dengan mengubah jenis matrik dan serat yang digunakan. Bahkan dimungkinkan untuk menggabungkan lebih dari satu jenis serat dan matrik menghasilkan komposit hibrid.

Dari segi proses produksi, komposit dapat diproses dengan berbagai teknik fabrikasi. Misalnya komposit termoplastik dapat difabrikasi dengan teknik umum yang biasa digunakan untuk pemroses polimer termoplastik tanpa serat.

Kekuatan komposit sangat dipengaruhi oleh bentuk serat, fraksi volume serat, orientasi serat, serta zat aditif yang ditambahkan. Secara teoritis semakin tinggi fraksi volume serat maka kekuatan komposit semakin tinggi dan sebaliknya.

Perbandingan matrik dan penguat dapat ditunjukkan dalam bentuk fraksi volume serat (Vf) atau fraksi berat serat (wf). Namun formulasi kekuatan komposit lebih banyak menggunakan fraksi volume serat [2].
Menurut Roe dan Ansel, fraksi volume serat dapat dihitung menggunakan persamaan berikut [3]

$v_{f}=\frac{\left[v_{c}-\left(\frac{M_{c}-M_{f}}{Q_{M}}\right)\right]}{V_{c}}$

Jika selama proses pembuatan komposit diketahui massa serat dan matrik, serta massa jenis serat dan matrik, maka fraksi volume dan fraksi massa serat dapat dihitung dengan persamaan [4] :

$$
\begin{gathered}
v_{f}=\frac{\frac{W_{f}}{\rho_{f}}}{\frac{W_{f}}{\rho_{f}}+\frac{W_{M}}{\rho_{M}}} \\
w_{f}=\frac{\rho_{f} \cdot v_{f}}{\rho_{f} \cdot v_{f}+\rho_{M} \cdot v_{M}}
\end{gathered}
$$

Fraksi massa serat pada persamaan di atas dapat disederhanakan menjadi :

$$
w_{f}=\frac{W_{f}}{W_{c}}
$$

Analisis kekuatan komposit dilakukan dengan mengasumsikan ikatan serat dan matrik sempurna. Pergeseran antara serat dan matriks diasumsikan tidak ada dan deformasi serat sama dengan deformasi matrik. Kekuatan tarik dapat dihitung dengan persamaan :

$$
\sigma=\frac{P}{A}
$$

Regangang dapat dihitung dengan persamaan :

$$
\varepsilon=\frac{\Delta l}{l_{0}}
$$

Berdasarkan kurva uji tarik, modulus elastisitas dapat dihitung dengan persamaan (7) [5].

$$
E=\frac{\Delta \sigma}{\Delta \varepsilon}
$$


Dimana :

$\Sigma=$ Tegangan tarik komposit $(\mathrm{GPa})$

$\varepsilon=$ Regangan pada arah longitudinal

\subsection{Penggunaan Serat Alam pada Komposit}

Serat alam berpotensi menurunkan berat kendaraan sampai dengan $40 \%$ dibanding serat gelas, yang saat ini dominan digunakan pada komposit di kendaraan. Serat alam diperoleh dari tanaman pisang, bambu, nanas, rosella, kelapa, kenaf dan lain-lain. Keunggulan serat alam yaitu :

1. Memiliki berat jenis yang rendah sehingga kekuatan spesifiknya tinggi,

2. Ketersediaannya.

Serat alam mudah didapat, merupakan sumber daya alam yang dapat diperbaharui, murah dan tidak beracun.

Tabel 1. Berat Jenis Berbagai Jenis Serat Alam

\begin{tabular}{|l|l|}
\hline \multicolumn{1}{|c|}{ Serat } & Berat jenis \\
\hline Eceng gondok & $0,25 \mathrm{~g} / \mathrm{cm}^{3}$ \\
\hline Tebu & $0,36 \mathrm{~g} / \mathrm{cm}^{3}$ \\
\hline Kelapa & $0,36 \mathrm{~g} / \mathrm{cm}^{3}$ \\
\hline
\end{tabular}

Ampas tebu merupakan salah satu sumber serat alam alternatif yang dapat dikembangkan dalam pembuatan komposit dan sejauh ini belum ditemukan material komposit yang menggunakan penguat ampas tebu.

Tebu atau yang dalam bahasa latin saccharum officinarum adalah tanaman bahan baku gula. Tanaman ini hanya dapat tumbuh di daerah beriklim tropis dan termasuk jenis rumputrumputan. Di Indonesia, tebu dibudidayakan di pulau Jawa dan Sumatera.

Ampas tebu atau yang dikenal dengan istilah bagas adalah hasil samping dari proses ekstraksi cairan tebu. Dari satu pabrik dihasilkan ampas tebu sekitar 35 - $40 \%$ dari berat tebu yang digiling. Pada musim giling 2006, data yang diperoleh dari ikatan ahli gula Indonesia menunjukan bahwa jumlah tebu yang digiling oleh 57 pabrik gula di Indonesia mencapai 30 juta ton, sehingga ampas tebu yang dihasilkan diperkirakan mencapai 9 juta ton. Sebanyak 60\% dari ampas tebu tersebut dimanfaatkan oleh pabrik gula sebagai bahan bakar, bahan baku untuk kertas, bahan baku industri kanvas rem, industri jamur, dan sebagainya. Oleh karena itu diperkirakan sebanyak $40 \%$ dari ampas tebu tersebut belum banyak dimanfaatkan. Bagi pabrik gula ampas tebu merupakan limbah yang menimbulkan masalah bila musim kemarau karena dapat terbakar [6].

Dari aspek ekonomis, ampas tebu mudah di dapat dan ketersediaannya cukup melimpah, murah, dan penggunaannya dapat mengurangi polusi lingkungan dan tidak membahayakan kesehatan.
Tabel 2. Kandungan Ampas Tebu

\begin{tabular}{|l|c|}
\hline \multicolumn{1}{|c|}{ Kandungan } & Kadar (\%) \\
\hline Air & $46-52$ \\
\hline Serat & $43-52$ \\
\hline Padatan terlarut & $2-6$ \\
\hline
\end{tabular}

Kandungan terbesar dari ampas tebu adalah lignin dan selulosa. Panjang serat antara 1,7 - $2 \mathrm{~mm}$ dengan diameter $20 \mathrm{~mm}$. Serat tebu tidak dapat larut dalam air dan sebagian besar terdiri dari selulosa, pentose dan lignin.

Tabel 3. Komposisi Kimia Ampas Tebu

\begin{tabular}{|l|c|}
\hline \multicolumn{1}{|c|}{ Kandungan } & Kadar (\%) \\
\hline Abu & 3,82 \\
\hline Lignin & 22,09 \\
\hline Selulosa & 37,65 \\
\hline Sari & 1,81 \\
\hline Pentosa & 27,97 \\
\hline SiO2 & 3,01 \\
\hline
\end{tabular}

\section{PROSEDUR PENELITIAN}

\subsection{Pembuatan Komposit}

a. Resin polyester dan serat masing-masing diukur dengan perbandingan volume tertentu. Volume total disesuaikan dengan volume cetakan.

b. Resin dan serat dicampurkan dan ditambahkan katalis sebanyak 2,5\% dari volume resin, kemudian diaduk rata dan didiamkan selama 5 menit agar gelembung udara hilang.

c. Campuran dituang ke dalam cetakan dan dibiarkan pada suhu kamar selama 2 hari. Setelah benar-benar keras lalu dikeluarkan dari cetakan.

d. Dilakukan pengamatan pada komposit terhadap ada tidaknya void, kekasaran permukaan, dan perbedaan ketebalan akibat penyusutan.

e. Spesimen uji dibentuk sesuai dengan standar ASTM 638

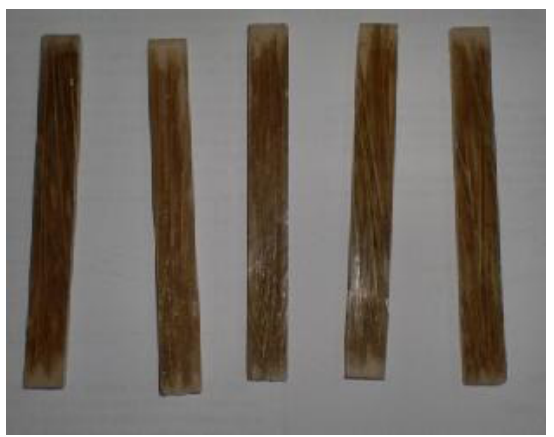

Gambar 1. Komposit serat tebu/poliester

\subsection{Pengujian Mekanik}

Terhadap semua spesimen dengan berbagai macam komposisi dilakukan pengujian tarik dengan menggunakan mesin uji tarik dengan 
kapasitas beban maksimum 10 ton. Hasil yang diperoleh adalah kurva uji tarik tegangan dan regangan tegangan teknis, yang selanjutnya diekstrak untuk memperoleh nilai kekuatan tarik, kekakuan dan ketangguhan.

\section{HASIL PENELITIAN DAN PEMBAHASAN}

\subsection{Sifat Mekanik Komposit Serat Tebu/Poliester}

Pada tabel tersebut terlihat bahwa kekuatan tarik komposit serat tebu/poliester lebih besar dibandingkan dengan kekuatan tarik dari matrik poliester $100 \%$ yang digunakan, yaitu sebesar 12,5 MPa. Hal ini menunjukkan bahwa dengan adanya penambahan serat tebu terhadap resin poliester, maka kekuatan tariknya meningkat.

Peningkatan yang sama juga terjadi pada modulus elastisitas dan ketangguhan dari resin poliester. Setelah ditambahkan serat tebu modulus elastisitasnya menjadi lebih besar dari $568 \mathrm{MPa}$ dan ketangguhannya naik menjadi lebih besar dari 27,5 Joule. Hal ini menunjukkan bahwa setelah ditambahkan serat tebu, komposit yang terbentuk menjadi lebih kaku dan menyerap lebih banyak energi untuk mematahkannya.

\subsection{Pengaruh Fraksi Volume Serat terhadap Kekuatan Tarik}

Nilai kekuatan tarik komposit serat tebu/poliester yang diperoleh dari pengujian tarik komposit ditampilkan pada gambar 2. Nilai kekuatan tarik masing-masing fraksi volume serat yang diperoleh sebagai berikut, untuk fraksi serat $5 \%$ kekuatan tarik 14,4 MPa, fraksi volume $15 \%$ kekuatan tarik 17,6 MPa, fraksi volume $25 \%$ kekuatan tarik 20,5 $\mathrm{MPa}$, dan fraksi volume $35 \%$ kekuatan tarik $23 \mathrm{MPa}$. Hal ini menunjukkan bahwa kekuatan tarik meningkat dengan bertambahnya fraksi volume serat yang terkandung pada komposit serat tebu/polyester atau dengan kata lain komposit tersebut semakin kuat.

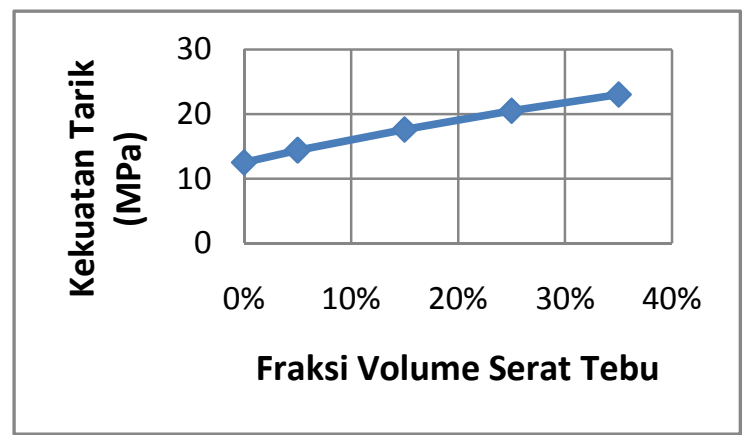

Gambar 2. Pengaruh Fraksi Volume Serat Tebu terhadap Kekuatan Tarik

\subsection{Pengaruh Fraksi Volume Serat terhadap Kekakuan}

Hubungan antara fraksi serat dengan kekakuan komposit diperlihatkan pada gambar 3 . Modulus elastisitas komposit diperoleh dari gradien kurva uji tarik pada daerah linier. Hasil yang diperoleh adalah sebagai berikut modulus elastisitas komposit dengan fraksi volume serat $5 \%$ sebesar 652MPa, fraksi volume serat $15 \%$ sebesar $786 \mathrm{MPa}$, fraksi volume serat $25 \%$ sebesar 827 $\mathrm{MPa}$, dan fraksi volume serat $35 \%$ sebesar 885 $\mathrm{MPa}$. Dari hasil tersebut menunjukan bahwa dengan bertambahnya fraksi volume serat, kekakuan komposit semakin meningkat, sehingga jika diberi beban tarik yang sama, maka komposit dengan fraksi volume serat yang lebih tinggi akan mengalami regangan yang lebih kecil.

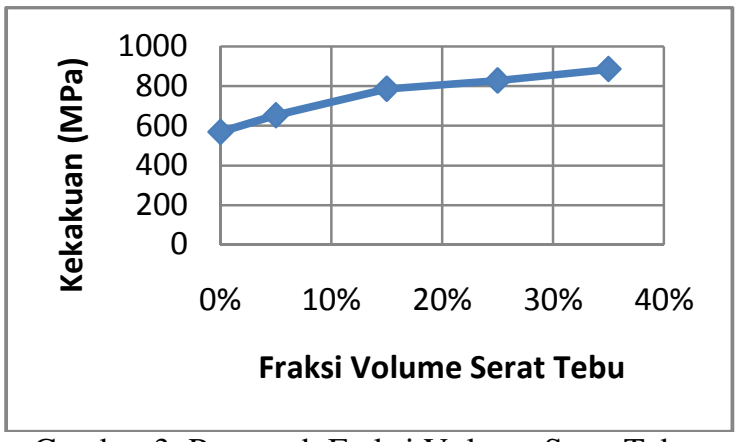

Gambar 3. Pengaruh Fraksi Volume Serat Tebu terhadap Kekakuan

\subsection{Pengaruh Fraksi Volume Serat terhadap Ketangguhan Komposit}

Nilai ketangguhan dari komposit serat tebu/poliester untuk berbagai komposisi serat ditampilkan pada gambar 4. Ketangguhan diperoleh dari luas daerah dibawah kurva uji tarik atau dengan melakukan pengujian impak. Dari data ketangguhan dapat diketahui energi yang diserap oleh material komposit untuk mematahkannya dan juga menunjukkan ketahanan material dalam menahan beban secara tiba-tiba.

Ketangguhan komposit dengan fraksi volume serat 5\% sebesar 31,8 Joule, fraksi volume serat $15 \%$ sebesar 39,4 Joule, fraksi volume serat $25 \%$ sebesar 50,8 Joule, dan fraksi volume serat $35 \%$ sebesar 59,8 Joule. Dari hasil tersebut menunjukan bahwa dengan bertambahnya fraksi volum serat, ketangguhan komposit semakin meningkat. 


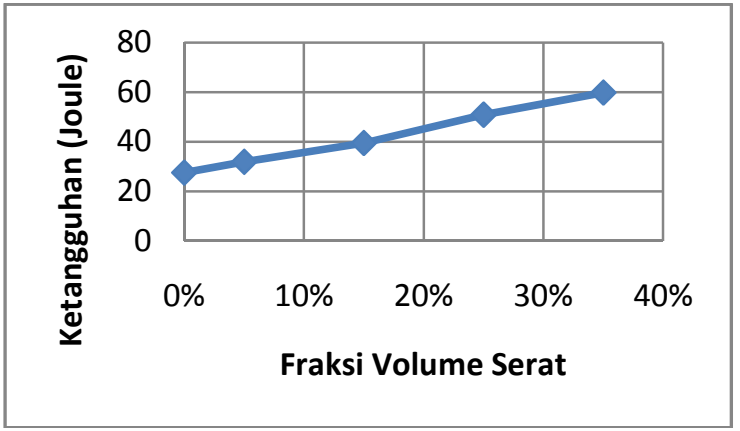

Gambar 4. Pengaruh Fraksi Volume Serat Tebu terhadap Ketangguhan

\subsection{Pengaruh Konsentrasi Hardener terhadap Sifat Mekanik Komposit}

Pada penelitian ini digunakan resin poliester dengan hardener metal etil keton peroksida dengan komposisi 2,5\%(v/v). Kadar hardener yang ditambahkan menentukan sifat mekanik dari komposit yang dihasilkan. Jika komposisi hardener berlebih mengakibatkan ikatan matrik dengan penguat tidak kuat, karena matrik mengeras lebih cepat, sebelum ikatan antara matrik dan serat terbentuk sempurna. Sebaliknya jika hardenernya kurang banyak maka kerapatan jaringan yang terbentuk pada rantai polimernya berkurang sehingga fungsi matrik polimer sebagai pendukung serat dalam mendistribusikan beban tidak maksimal .

Hal ini terlihat pada kadar hardener 5\% dan $2,5 \%$ untuk fraksi serat $5 \%$ terlihat perbedaan kekuatan tarik dan keuletan seperti grafik pada gambar 5 dan 6 .

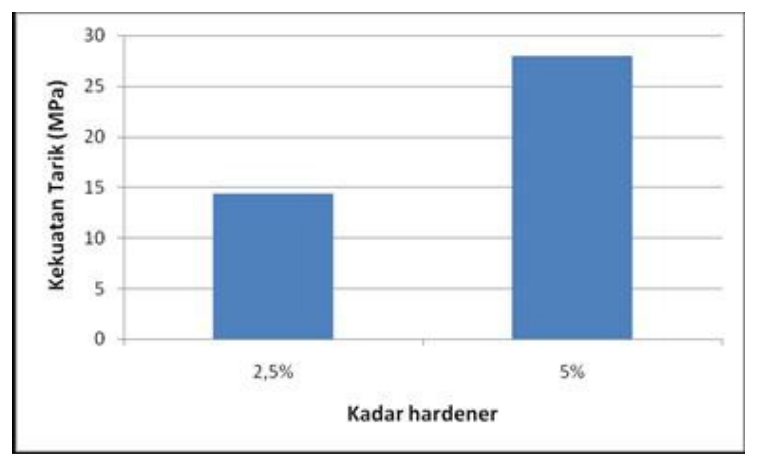

Gambar 5. Pengaruh Kadar Hardener Yang Ditambahkan Terhadap Kekuatan Tarik

Pada gambar 6 ditampilkan hubungan antara kadar hardener yang ditambahkan dengan kekuatan tarik. Kekuatan tarik pada komposit dengan persentase hardener $2,5 \%$ adalah $14,4 \mathrm{MPa}$ lebih rendah dibandingkan komposit dengan 5\% hardener, yang memiliki kekuatan tarik $28 \mathrm{MPa}$.

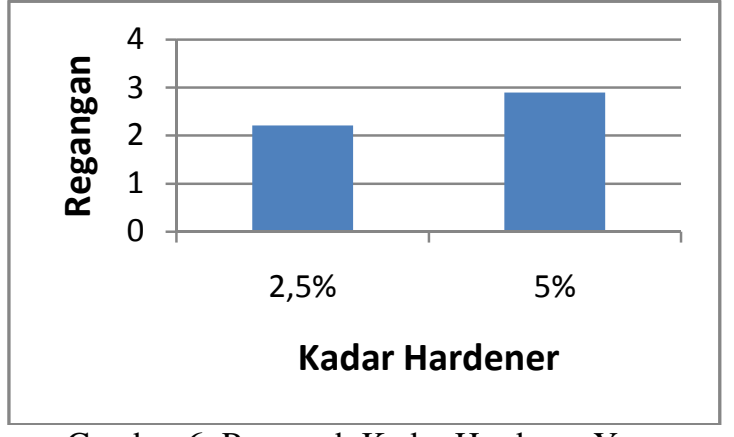

Gambar 6. Pengaruh Kadar Hardener Yang Ditambahkan Terhadap Keuletan

\section{KESIMPULAN}

1. Komposit serat tebu/poliester dengan fraksi volume 35\% memiliki kekuatan tarik $23 \mathrm{MPa}$, kekakuan 885 MPa dan ketangguhan 59,8 Joule.

2. Pada komposit serat tebu/poliester dengan fraksi volume $15 \%$ - 35\%, kekuatan tarik, kekakuan dan ketangguhan meningkat dengan bertambahnya fraksi serat yang terkandung pada komposit tersebut.

\section{DAFTAR PUSTAKA}

1. Astrom, B.T., Manufacturing of Polymer Composite, first edition, Chapman \& Hall, London, 1997.

2. Diharjo, K., The Flexural and Impact Properties of Random and Woven kenaf Fiber Reinforced Polyester Composite, Proseding SNTTM-IV, 2005.

3. Roe P.J., Ansel M.P., Jute-Reinforced Polyester Composite, Journal of Materials Science, 1985 (20), 4015-4020.

4. Shackelford, Introduction of Material Science for Engineer, third edition, MacMillan Publishing Company, New York, 1997.

5. Kaw A.K., Mechanics of Composite Materials, CRC Press, New York, 1997.

6. Mubin, A., Upaya penurunan Biaya Produksi dengan Memanfaatkan Ampas Tebu sebagai Pengganti Bahan Penguat dalam Proses Produksi Asbes Semen,Jurnal Teknik Vol.5, 2005.

7. Lokantara, P., Analisis arah dan Perlakuan Serat Tapis serta Rasio Epoxy Hardener terhadap Sifat Fisis dan Mekanis Komposit Tapis/Epoxy, Jurnal Ilmiah Teknik Mesin CAKRAM, 2007 (1). 